\title{
Information System Strategic Planning in PT. XYZ Using Wetherbe's Methodology
}

\author{
Andi Sulistiawan \\ Information System, Kristen Satya Wacana University, \\ Salatiga, 50715, Indonesia \\ 682016036@student.uksw.edu
}

\author{
Melkior Sitokdana \\ Information System, Kristen Satya Wacana University, \\ Salatiga, 50715, Indonesia \\ melkior.sitokdana@uksw.edu
}

\begin{abstract}
Along with the development of technology in business, PT. XYZ, which is engaged in the food industry, which is located in Sidomukti, Salatiga City is required to be adaptive and innovative by utilizing the availability of information technology. In order to win the competition, and information system strategic plan is needed to support the implementation of information technology and information systems in terms of operations as well as for strategic ones. Therefore, this research conducted by making strategic planning of information systems for use at PT. XYZ using the Wetherbe methodology. This methodology is considered as an appropriate approach tool for the company. The solution for information system requirements is based on the strategic planning analysis that has been carried out, namely, producing nine information systems consisting of one information system to be developed from existing applications and eight information systems for the proposed application. And IT personnel are needed for the database and network server work or to carry out proper training for each employee so that if there is damage to the system and infrastructure it can be directly handled. This was done due to the condition of the number of human resources and limited funds for the strategic planning of information systems.
\end{abstract}

Keywords-Information System Strategic Planning, Wetherbe Methodology.

\section{INTRODUCTION}

Information technology develops in line with the development of human civilization that affects all fields. Along with the development of PT. XYZ is required to be adaptive and innovative by utilizing the availability of Information Technology. By implementing information technology will help organizations in all aspects, such as work processes, marketing, and even strategic management support. Besides accelerating the growth of the company with increasing advantages and competitive advantages.

The use of technology which refers to strategic information technology planning is a must to maintain organizational excellence. The development of information technology encourages various organizations to make more use of information as support for organizational success in achieving the goals. Information is a very important asset for a company that is useful in the long term. To be able to utilize information optimally, every company needs to have a system that can manage information to make it efficient. It takes speed and accuracy of information when various problems and their level of complexity need to be processed in order to get an effective, efficient solution for each problem. As generally understood, the role of strategic planning in information systems is needed to obtain fast and precise information (Supriyantoko, 2018)

Organizations at PT. XYZ is an organization which is located in Mangunsari, Sidomukti, Salatiga. This organization is engaged in the hospitality food industry, bakery or cake, and bread products, starting from a simple desire to present a different taste and to provide jobs for the people of Salatiga City. Thus PT. XYZ places great importance on the role of information systems in its work environment so that it is expected to provide a competitive advantage. Within the PT. XYZ can be seen that this organization attaches great importance to the role of information technology as the main spear for success in the progress of the organization it runs, proven to have used hardware, software, and network facilities. So that PT. XYZ can win the competition, so an Information System Strategic Plan is needed to support investment and implementation of information technology and information systems in operational terms as well as for strategic ones. To design strategic information systems planning, a methodology is needed that is appropriate to the conditions of the organization. The methodology used in this research is the Wetherbe methodology. This methodology will produce information system strategic planning consisting of, analysis of information needs, allocation of information system resources, and project planning. The hope of this research is to produce an information system strategic planning document for the organization of PT. XYZ.

\section{LITERATURE REVIEW}

\section{A. Previous Research}

Research conducted by Bambang Eko Supriyanto (2018), entitled "Strategic Planning of Information Systems and Information Technology for Vocational High Schools Using the Wetherbe Methodology. Case Study: SMK Avicena Rajeg", the results of this research 
is an information system strategic plan to develop academic school applications from registration application to graduation application, in order to improve the quality and excellence you want to expect (Supriyanto, 2018).

Research conducted by Yusuf P, Irwan I, Utami S (2011) entitled "Executive Information Design for Academic and Student Affairs at Universitas Sebelas Maret". The results of this research are to produce several internal and external information needs in the academic and student affairs fields. (Priyandari, Iftadi, Sundari, 2011).

Research by Nicka Puspita S (2013) entitled "Strategic Planning of Information Technology in Islamic boarding school Annur II AL-Murtadlo Malang using the Wetherbe Method". The results of this study are a portfolio of information technology applications in accordance with the vision and mission description of Islamic boarding schools (Sriminangga, 2013).

Research conducted by Asri Mulyani (2017), entitled "Strategic Planning of Animal Park Information Systems Using Ward and Peppard Methodology", the results of this research resulted in strategic and effective implementation of information systems, by conducting PEST analysis, SWOT analysis, Value Chaine analysis., MOST Analysis, CFS Analysis, IS Strategy (Mulyani, 2017).

Research conducted by Iwan Supriyantoko (2018), entitled "Strategic Planning of Information Systems at SMK Diponegoro 1 Jakarta". The results of this research define the company by analyzing information systems with the results of information systems business strategy, management strategy, information system strategy, recommendations future systems, and plans for implementing information systems (Supriyantoko, 2018).

Research by Anharudin (2015), entitled "Information Systems Strategic Planning to Improve Services Using the Ward and Peppard Method", From the results of the PT Pos analysis, namely the strategic planning of information systems at PT Pos Cilegon can be used to harmonize business conditions and information system conditions to add added value and a competitive advantage for the company (Anharudin, 2015).

\section{B. Theoretical Basis}

a) Information System

Information system is a system that collects, processes, stores, analyzes, and disseminates information for a more specific purpose (Turban, Waterbe, and McLean 1999). The study of information systems includes theory and practice related to social and technological phenomena that determine the development, utilization, and influence of information systems in community organizations (Kusuma, Wahyu Haris 2002).

b) Information Technology

Information Technology is a technology used to process data, including processing, obtaining, compiling, storing, and manipulating data in various ways to produce quality information, namely information that is relevant, accurate, and timely, which is used for personal, business, and government. In addition, information technology is strategic information for decision making (Saputri, 2015).

c) Strategic Planning

According to James Martin (Kridanto Surendro (2009: p4), information strategic planning is part of the information engineering methodology used to identify strategies for achieving the vision and mission of information systems through the management and development of information systems. Information strategic planning is based on the explanation above, it can be concluded that the definition of information strategic planning is preparing the design and development of computer-based systems

d) Information System Strategic Planning Information systems strategic planning is the process of identifying a computer-based information system application portfolio that will support an organization in implementing its business plan and realizing its business objectives (Rusdiana et al, 2014). Information systems strategic planning studies the influence of information systems on business performance and the contribution to organizations in choosing strategic steps. In addition, information system strategic planning also describes various tools, techniques, and frameworks for management to align information system strategy with business strategy, even seeking new opportunities through the application of innovative technology (Wedhasmara, 2009).

e) Wetherbe's Methodology

According to Wetherbe (2006: p520), there are several models that have been developed to facilitate system planning and information technology. One of them is Wetherbe's planning model. The Wetherbe planning model, also known as the four-stage model of planning. The four activities are IT strategic planning, information needs analysis, resource allocation, and project planning. The explanation is as follows:

1. IT strategic planning: Establishing the relationship between the overall plan of the organization and the information technology plan

2. Information requirements analysis: Identify in detail the information needs required by the organization

3. Allocation of resources: Allocating resources for information technology applications and operational resources

4. Project planning: Developing a plan that outlines an information system project schedule 


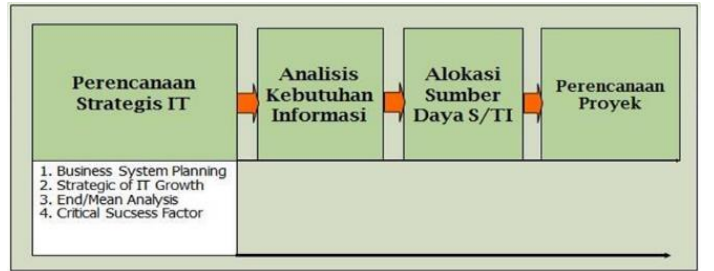

Figure 1. The Wetherbe Version of Strategic

Planning Model for Information Systems

This four-stage modeling is the basis for developing a portfolio of applications, both of which are very much in line with the company's goals and have the ability to make an advantage over competitors. An explanation of each stage is as follows:

1. IT Strategic Planning

This stage of strategic information technology planning includes several types that are somewhat different from other activities. On the one hand, it refers to identifying an organization's applications for implementing business strategy in a competitive environment. On the other hand, information technology strategic planning can refer to the creation of information system applications that allow an organization to develop a competitive advantage. To achieve this goal, organizations have to do some creative thinking. Namely understanding the capabilities of existing systems and looking ahead to how IT systems can generate future profits for the organization.

2. Information Requirements Analysis-IRA

IRA is an analytical activity carried out to find out the detailed information needs required by the organization as a whole. The purpose of this stage is to ensure that information systems, databases, and networks can be integrated to support identification in stage 1 . The results of the information need analysis are threefold. Namely identifying categories of information, providing the basis for IT architecture and resource allocation. This IRA analysis can be done with a Five-steps process

3. Resource Allocation

Resource Allocation is a planning activity to develop software, hardware, computer networks, facilities, personnel, other resources, and financial plans required to carry out development. In accordance with the plan that has been prepared in the information needs analysis (IRA). This stage provides an overview of the technology, labor procurement, and identifies the financial resources required to provide the appropriate level of service to users. The allocation of resources is a contentious process in most organizations because the opportunities and demands for spending far exceed available funds. This can lead to intense, competition between organizational units, which makes it difficult to identify the most desirable investments.

4. Project Planning

Project planning includes system development activities according to a planned, scheduled and controlled framework

\section{RESEARCH METHODS}

The methodology concept in this study uses a qualitative method that aims to describe and analyze the social activities that occur. Qualitative methods are obtained through problems arising from field data.

Stage 1. At this stage, the authors identify the problems faced by PT. XYZ through observation and literature review. The identified problems become the basis for compiling the Information System Strategic Planning at PT.XYZ.

Stage 2. At this stage, the authors review various studies such as literature studies which are the references in this study, including examining the theoretical basis of Information Systems Strategic Planning using the Wetherbe Methodology.

Stage 3 data collection, as for this study consists of two data sources, namely primary data and secondary data. Data collection in this study was carried out by the following methods:

a) Observation: Doing observations in the PT.XYZ environment, by observing and seeing directly the condition of PT.XYZ.

b) Interview: Interviews were conducted directly with sections or divisions that understand the condition of PT. XYZ, namely Mrs. Mega.

Stage 4 Information Systems Strategic Planning using the Wetherbe Method.

a) Analysis of the business environment, in analyzing the internal business environment, Value Chain, Critical Success Factors (CSF), Resource-Based View (RBV) analysis tools are used. PEST analysis is used to analyze the external business environment.

b) Analysis of information systems environment, in analyzing the environment of internal and external information systems at PT.XYZ. McFarlan matrix analysis is used for the analysis of internal information systems, and internal analysis of information technology by looking at the infrastructure of hardware, software, human resources, and network conditions. Meanwhile, to see the external analysis of information systems by looking at the development of information technology systems and other IT devices. 
Stage 5 Portfolio Mapping, Application Portfolio Mapping using the MC Farlan Strategic Grid. The results obtained by using the MC Farlan strategic grid is to map the information system application at PT. XYZ based on their contribution. And the mapping is conducted in four categories, namely: strategic, high potential, key operation and support.

Stage 6 of the Implementation Plan, which is a description of the company in implementing the required information system.

Stage 7 Conclusion, to conclude the results of the information systems strategic planning analysis.

\section{RESULTS AND DISCUSSION}

\section{A. Organization Profile}

PT. XYZ is an organization which is located in Mangunsari, Sidomukti, Salatiga. This organization is engaged in the hospitality food industry, bakery or cake, and bread products, starting from a simple desire to present a different taste and to provide jobs for the people of Salatiga City. PT. XYZ chooses a business in the food industry because this business is tailored to the needs and skills possessed as well as sufficient supporting factors to develop this business.

B. Vision and Mission

a) Vision

Make customers enjoy the bread and cake products from PT. XYZ is more satisfied

b) Mission

1. Prepare fresh bread, by giving a small amount of preservative.

2. Providing the best service from PT. XYZ.

3. Providing quality products at affordable prices.

\section{External business analysis using PEST}

After conducting interview observations, a PEST analysis process is carried out, PEST analysis is used to see the strength of external environmental factors that can affect the business processes of the company. These external factors include Political, Economic, Social, and Technological. The following is the PEST analysis obtained at PT. XYZ:

a) Politics

Conditions of conducive environmental issues could allow PT. XYZ to run its business processes well. Based on the regulations of Law Number 20 of 2008 concerning Micro, Small and Medium Enterprises (State Gazette of the Republic of Indonesia of 2008 Number 93, Supplement to the State Gazette of the Republic of Indonesia Number 4866), Chapter II Principles and Objectives of Article 2 stipulates that Micro, Small and Medium Enterprises based on environmental awareness. Referred to as "environmental principles" is the principle of empowering Micro, Small, and Medium Enterprises which is carried out by still paying attention to and prioritizing environmental protection and maintenance. As a government policy, Chapter VI
Article 20 regulates that the Government and Regional Governments facilitate business development by providing incentives for Micro, Small, and Medium Enterprises to develop technology and environmental sustainability. So that requires the company PT XYZ to be more effective and creative in promoting products

b) Economy

Judging from the economic conditions, an income of people, or customers around PT. XYZ is relatively moderate. Price increases and inflation can become economic factors in society. Economic factors are related to people's purchasing power, business climate, and company operating costs. Domestic and foreign economic situation, currency exchange rates, taxes, inflation, working wage interest rates, stock market and consumer confidence, domestic economic trends, foreign economic trends, taxes on certain goods, recurring economic issues, trade cycles and market, industry-specific aspects, trends in market direction and distribution, customer and trigger issues, bank interest rates and exchange rates, monetary issues, and international trade. If the US dollar exchange rate is difficult to control, high bank interest rates, applicable taxes, per capita income, and other monetary issues, companies must carefully anticipate them. However, the opportunity that can be obtained is the increase in the amount and value of consumer purchases, while the challenge faced is the determination of the selling price of goods which must be dynamic. So that requires companies to be better and more efficient in managing existing human resources so that the company's economy does not decline and remains stable.

c) Social

These social factors center on the assessment of the attitudes of consumers and employees that influence the strategy. Social mobility factors and work attitudes of the employees of PT. XYZ will also have a high impact. Good service to consumers is a very positive thing that is done and also emphasized by PT. XYZ. Therefore, good service will have a good influence on consumers when buying and will feel interested in visiting PT. XYZ is standing.

d) Technology

The development of information technology that is increasingly rapid in Indonesia begins with the existence of the internet, computer networks, and mobile services which are increasingly having an impact on human life. Internet users are very influential on the behavior of producers and consumers to carry out reciprocal promotions or order products offered by PT. XYZ. In general, the impact of technological changes on PT XYZ has a positive effect because it will indirectly increase profits.

D. Internal business environment analysis (Value Chain, CSF, RBV)

The following is an analysis of the internal business environment, with Value Chain analysis techniques to 
understand the various competitive advantages that cover the business processes that are running at PT. XYZ. So that we get an overview of the strategic planning of information systems that can meet the needs of the company. Where the existing business processes at PT. $\mathrm{XYZ}$ has two activities, namely main activities and supporting activities.

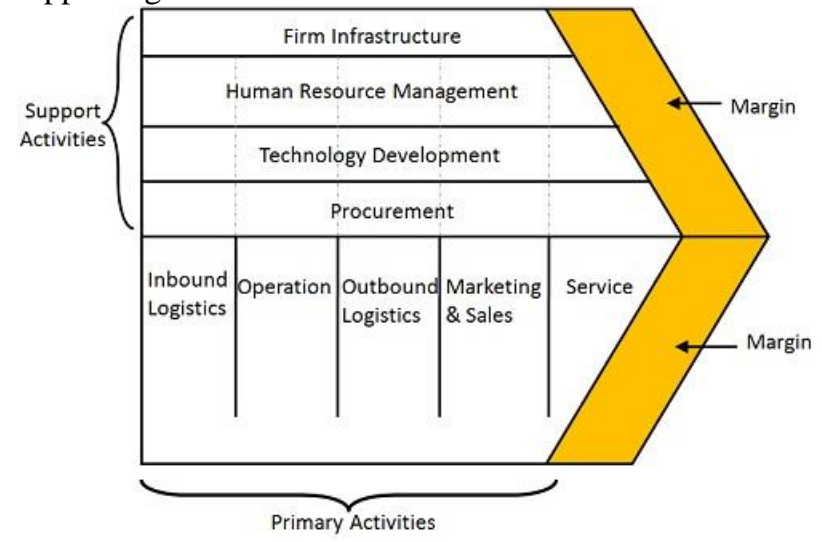

Figure 2. Value Chain

Based on Figure 2, it is made as follows:

a) Main Activity consists of:

1. Inward Logistics

- Storage of raw material data

- Storage of stock items at outlets

- Storage of order data

- Storage of return data

2. Operation

- Ordering raw materials

- Checking raw materials

- Bread production

- Delivery of goods to branch outlets

- Sales of bread

- Payments from customers

- Checking bread stock

3. Logistics Out

- Issuance of bread products

- Delivery of ordered goods

- Order settlement

4. Marketing

- Through outlets

- Promotion through advertisements, posters

5. Services

- Services that prioritize friendliness, fresh, hygienic, enjoyable

- Affordable prices for all people

b) Support Activity consist of :

1. completeness Infrastructure

- Management of company business

- Availability of supporting equipment

2. Human Resource Management

- Recruitment Selection

- Employee training and evaluation to improve performance
- employee payroll process

3. Technology development

- Developing information systems required for company requisite

\section{E. Critical Success Factors (CSF) Analysis}

CSF is used to determine the desired business process factors of PT. XYZ, by connecting business strategic and strategic information systems, focusing on the strategic planning of information systems in strategic areas. Based on the objectives of PT. XYZ, namely to be organized, to open jobs, to obtain the optimal trust from consumers, so that with the trust given, it is hoped that the business that has been carried out can be more developed. The following is a clearer objective interpretation to determine what activities are carried out and what information is required.

Table 1. Critical Success Factors (CSF) Analysis

\begin{tabular}{|c|c|c|}
\hline Strategy & CSF & IT Requirement \\
\hline $\begin{array}{l}\text { Develop a cashier, } \\
\text { sales and purchases } \\
\text { system }\end{array}$ & $\begin{array}{l}\text { Desktop } \\
\text { Programming }\end{array}$ & $\begin{array}{l}\text { Cashier, Sales and } \\
\text { Purchasing } \\
\text { Information Systems }\end{array}$ \\
\hline $\begin{array}{lr}\text { Developing } & \text { an } \\
\text { inventory } & \text { stock } \\
\text { system } & \\
\end{array}$ & $\begin{array}{l}\text { Desktop } \\
\text { Programming }\end{array}$ & $\begin{array}{l}\text { inventory } \\
\text { information system }\end{array}$ \\
\hline $\begin{array}{l}\text { Developing } \\
\text { administrative and } \\
\text { financial information } \\
\text { systems }\end{array}$ & $\begin{array}{l}\text { Desktop } \\
\text { Programming }\end{array}$ & $\begin{array}{l}\text { Administrative and } \\
\text { financial information } \\
\text { systems }\end{array}$ \\
\hline $\begin{array}{l}\text { developing web } \\
\text { information systems }\end{array}$ & Interactive Website & $\begin{array}{l}\text { web information } \\
\text { system }\end{array}$ \\
\hline
\end{tabular}

\section{F. Resource Based View (RBV) Analysis}

RBV focuses on the competencies and resources owned by the organization. Here is the resource-based view of PT. XYZ.

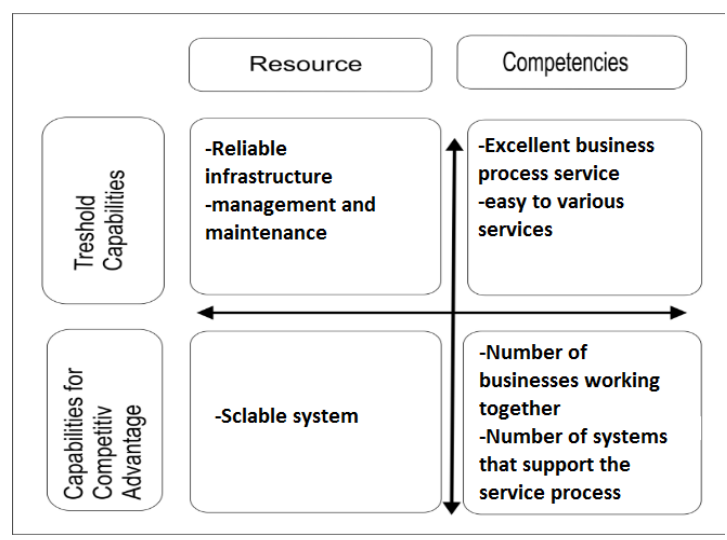

Figure 3. RBV Analysis

\section{G. Internal Analysis of Information Systems}

PT.XYZ does not yet have an integrated system for business processes so that PT.XYZ experiences competitiveness with other companies in terms of business. Currently, PT XYZ only has a very weak information system, the information system is only in the key operational and support areas, and does not yet have an information system that is strategic or high potential. 
The following is the information system owned by PT. XYZ based on the McFarlan matrix analysis on Tabel 2.

Table 2. McFarlan Matrix

\begin{tabular}{|l|l|}
\hline Strategy & High Potential \\
\hline available & Not available \\
\hline$-\quad$ Information System & - Graphic Design Software \\
$-\quad$ MS Office & $-\quad$ Antivirus \\
\hline$\quad$ Web Browser & \\
\hline Key Operational & Support \\
\hline
\end{tabular}

H. Internal Analysis of Information Technology

Internal analysis of Information Technology at PT. $\mathrm{XYZ}$ is conducted by observing the company's current infrastructure, including hardware, software, human resources, and networks for business processes at PT. XYZ :

a) Hardware

As for the existing hardware at PT. XYZ, Computers / Laptops, Printers, and CCTV. Computers/laptops owned by PT. XYZ currently has 7 units with dualcore processor specs, with $512 \mathrm{MB}$ and $2 \mathrm{~GB}$ memory, with the following explanation:

1. Office room 3 PC units, 3 printer units, 2, CCTV

2. Cashier Unit 3 PC Unit, 2 Printer Unit

3. Production Unit 1 PC Unit

4. Shop Section 2 CCTV Unit

5. Front Gate 1 CCTV Unit

6. Rear Gate 1 CCTV Unit

b) Software

1. Operating System Software

2. The software currently available on each computer uses the Windows 7 system because the device is more convenient for users to use

3. Application Software

4. Application software used by PT. XYZ to support current operations, namely Microsoft Office 2007 (Microsoft Word, Microsoft Power Point, Microsoft Excel), Corel Draw X5, Adobe Photoshop CS6 and the web to support the operation of PT. XYZ

5. None Database Software

6. None Programming Language Software

c) Human Resource

Human resources involved in using computer equipment at PT.XYZ, that is :

1. $1 \mathrm{HRD}$ in Office Room - non IT background

2. 1 Manager in Office Room - non IT background

3. 1 Admin in Office Room - Non IT background

4. 2 cashiers in Shop Room - Non IT background

5. 1 Cashier Admin in Shop Room - Non IT background

6. 1 person Production in Production Office Room Non IT background

d) Network

Network conditions that are applied to PT.XYZ is only limited to ordinary networks, not using a database server. The use is limited to an internet network that is connected to each other on every computer in the Office of the Manager, HRD, Administration, Cashier / Shop Admin.

\section{External analysis of information Systems}

The condition of Information Systems in the globalization era, developing in line with the development of human civilization that affects all fields, can be used as a competitive advantage to be able to compete with other companies. There are things that can be used by PT. XYZ to take advantage of the most advanced and accurate information systems, namely Datawarehouse and Business Intelligence (DWBI) and Datamining.

\section{J. External Analysis of Information Technology}

Information technology develops in line with the development of human civilization that affects all fields. Along with the development of the role of information technology, it can be felt by many companies that always want to develop and must be adaptive and innovative by taking advantage of the availability of Information Technology to meet market demands and also to meet customer needs if they don't want to be left behind. By implementing information technology will help organizations in all aspects, such as work processes, marketing, and even strategic management support. Besides accelerating the growth of the company with increasing advantages and competitive advantages. There are several trends that can be exploited by PT.XYZ, namely cloud computing, mobile applications, media tablets, and social communication and collaboration.

K. Information System Strategic Plan Solutions Strategic Business Information Systems

Strategic business information systems are solutions to information system requirements obtained from the results of the analysis, both internal and external analysis. Solutions for information system needs are obtained from the results of the analysis of critical success factors (CSF), the resource-based view (RBV), Value Chain, and PEST.

The analysis for strategic SI Business mapping, critical success factors (CSF), and resource-based view (RBV), this analysis produces information system solutions to influence the business success of PT. XYZ. Value Chain Analysis produces information system solutions by looking at the factors of business activities being carried out. PEST analysis produces an information system that can strengthen the business position of PT. XYZ.

The results of the mapping of business analysis and analysis of internal and external information systems, resulting in applications that suit the business needs of PT. XYZ are as table 3. 
Table 3. Mapping of Internal and External Analysis Results

\begin{tabular}{|c|c|c|}
\hline Information System & Module & Function \\
\hline Cashier System & Cashier & $\begin{array}{l}\text { Serves to make payment } \\
\text { transactions }\end{array}$ \\
\hline Inventory System & $\begin{array}{l}\text { Facilities and } \\
\text { Equipment }\end{array}$ & $\begin{array}{l}\text { Serves for processing } \\
\text { inventory data, managing all } \\
\text { facilities and devices }\end{array}$ \\
\hline Data mining & Datamining & $\begin{array}{l}\text { Serves to find all data so } \\
\text { that it can be the basis for } \\
\text { making decisions }\end{array}$ \\
\hline administration system & Admin & $\begin{array}{l}\text { Serves to process all types } \\
\text { of administration that run in } \\
\text { business services }\end{array}$ \\
\hline $\begin{array}{l}\text { Financial Information } \\
\text { System }\end{array}$ & $\begin{array}{l}\text { Accounting } \\
\text { System }\end{array}$ & $\begin{array}{l}\text { Serves to manage all } \\
\text { company finances }\end{array}$ \\
\hline WEB system & $\begin{array}{l}\text { Information } \\
\text { Management }\end{array}$ & $\begin{array}{l}\text { Serves to assist in the } \\
\text { promotion of company } \\
\text { products }\end{array}$ \\
\hline $\begin{array}{l}\text { HR Information } \\
\text { System }\end{array}$ & HR & $\begin{array}{l}\text { Serves for sustainable } \\
\text { human resource } \\
\text { management and } \\
\text { development }\end{array}$ \\
\hline $\begin{array}{l}\text { Data Warehouse and } \\
\text { Busines Inteligence }\end{array}$ & $\begin{array}{l}\text { Data } \\
\text { Warehouse } \\
\text { and Busines } \\
\text { Inteligence }\end{array}$ & $\begin{array}{l}\text { Serves to assist business } \\
\text { management in dealing and } \\
\text { making corporate strategy } \\
\text { decisions }\end{array}$ \\
\hline $\begin{array}{l}\text { IT Information } \\
\text { Systems }\end{array}$ & $\begin{array}{l}\text { IT } \\
\text { Management }\end{array}$ & $\begin{array}{l}\text { Serve to manage IT } \\
\text { Management requisite in } \\
\text { company minitoring }\end{array}$ \\
\hline
\end{tabular}

For information system solutions that have been mapped according to business needs, it will be mapped according to the information system functions that have been made into the McFarlan matrix. The results of this mapping will become a future application portfolio.

Table 4. Upcoming McFarlan Matrix

\begin{tabular}{|c|c|}
\hline Strategy & High Potential \\
\hline $\begin{array}{l}\text { Data warehouse and Business } \\
\text { Intelligence (DWBI) (x) }\end{array}$ & Data Mining (x) \\
\hline $\begin{array}{ll}\text { - } & \text { Inventory System (x) } \\
\text { - } & \text { Administrator System (x) } \\
\text { - } & \text { Financial System (x) }\end{array}$ & $\begin{array}{ll}- & \text { Cashier System }(\sqrt{ }) \\
- & \text { Web Information system } \\
& (\mathrm{x}) \\
- & \text { TBSP information system } \\
& (\mathrm{x}) \\
- & \text { IT information system }(\mathrm{x})\end{array}$ \\
\hline Key Operational & Support \\
\hline
\end{tabular}

Information of Table 4

(x) : For proposed applications

$(\sqrt{ })$ : For applications to be developed from existing applications

L. Strategic Information Systems Organization

Strategic Information system organization is very influential with the condition of the existing IT infrastructure, considering the current condition, IT management or the IT division is very much needed to manage all problems that occur in information system infrastructure and information technology in applications.

M. Validation of Development Requirements for information systems
Validation of information system development is a documentation step in developing applications for both existing and future applications by listing information systems. A list of system development validations will be provided to management at PT. XYZ for evaluation as a copy, which applications must be developed in business and applications that are currently prepared and applications in the future.

Table 5. Validation of Development Requirements for Information Systems

\begin{tabular}{|c|c|c|c|c|c|}
\hline \multirow[t]{2}{*}{ No. } & \multirow[t]{2}{*}{ Requirements } & \multicolumn{2}{|c|}{$\begin{array}{l}\text { Circumstances } \\
\text { requirements }\end{array}$} & \multicolumn{2}{|c|}{ Level Of need } \\
\hline & & $\mathrm{x}$ & $\sqrt{ }$ & $\mathrm{H} 1$ & $\mathrm{H} 2$ \\
\hline \multicolumn{6}{|c|}{ Key Operational } \\
\hline 1 & $\begin{array}{l}\text { Inventory } \\
\text { System }\end{array}$ & V & & 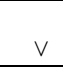 & \\
\hline 2 & Admin System & $\mathrm{V}$ & & & $\mathrm{V}$ \\
\hline 3 & Financial System & $\mathrm{V}$ & & $\mathrm{V}$ & \\
\hline \multicolumn{6}{|c|}{ Support } \\
\hline 1 & Cashier System & & $\mathrm{V}$ & & $\mathrm{V}$ \\
\hline 2 & $\begin{array}{l}\text { WEB Information } \\
\text { System }\end{array}$ & V & & 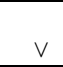 & \\
\hline 3 & $\begin{array}{l}\text { HR Information } \\
\text { System }\end{array}$ & V & & V & \\
\hline 4 & IT Information System & $\mathrm{V}$ & & $\mathrm{V}$ & \\
\hline \multicolumn{6}{|c|}{ Strategy } \\
\hline 1 & $\begin{array}{l}\text { Data Warehouse and } \\
\text { Business Intelligence }\end{array}$ & V & & $\mathrm{V}$ & \\
\hline \multicolumn{6}{|c|}{ High Potential } \\
\hline 1 & Datamining & $\mathrm{V}$ & & & $\mathrm{V}$ \\
\hline
\end{tabular}

Information of Table 5

(x) : For required applications

$(\sqrt{ }) \quad$ : For applications that will be developed from existing applications

(H1) : For applications that must be hastened

(H2) : It doesn't have to be hurried, but future time will be needed

N. Information System Development Roadmap

The design map is a direction for efforts to develop large-scale strategic systems, and for a long period of time. In an essence that occurs in system development, there are stages that are followed so as to achieve the expected development goals. Below is a table of the roadmap that has been designed for the future development process.

Table 6. RoadmapKey Operational

\begin{tabular}{|c|l|l|l|l|l|l|l|}
\hline \multirow{2}{*}{ No. } & \multicolumn{1}{|c|}{ Timeline } & \multicolumn{6}{|c|}{ Phase 1 } \\
\cline { 2 - 8 } & SI/TI & 1 & 2 & 3 & 4 & 5 & 6 \\
\hline \multirow{2}{*}{1} & Inventory & System & \multicolumn{6}{|c|}{} \\
\hline 2 & Admin System & \multicolumn{6}{|c|}{} \\
\hline 3 & Financial System & \multicolumn{7}{|c|}{} \\
\hline
\end{tabular}


Table 7. Roadmap Support

\begin{tabular}{|c|c|c|}
\hline \multirow{2}{*}{ No. } & Timeline & Phase 2 \\
\hline & Information System & 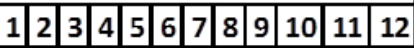 \\
\hline 1 & Cashier System & \\
\hline 2 & Web Information Systems & \\
\hline 3 & HR Information System & \\
\hline 4 & IT Information System & \\
\hline
\end{tabular}

Table 8. Roadmap Data Warehouse and Business Intelligence

\begin{tabular}{|l|l|l|l|l|l|l|l|}
\hline \multirow{2}{*}{ No. } & \multicolumn{1}{|c|}{ Timeline } & \multicolumn{6}{|c|}{ Phase 3 } \\
\cline { 2 - 8 } & Information System & 1 & 2 & 3 & 4 & 5 & 6 \\
\hline 1 & $\begin{array}{l}\text { Data Warehouse and } \\
\text { Business Intelligence }\end{array}$ & \multicolumn{6}{|c|}{} \\
\hline 2 & Admin System & \multicolumn{6}{|c|}{} \\
\hline
\end{tabular}

\section{CONCLUSION}

From the discussion of the results, the conclusion is drawn: This study proposes an analysis of information systems strategic planning as a solution to the problems that exist at PT. XYZ. The results of the analysis at PT. $\mathrm{XYZ}$, the system used in the field, which covers business processes, has not been well integrated. There is only one cashier system that is used for the sales, purchasing, inventory business processes. Therefore we need an information system that supports all business processes at PT. XYZ, with the construction of an integrated system according to existing business processes, and strategic planning to support the running of existing information systems, the results obtained are PT. XYZ will get new business opportunities so that it is more competitive in maximum competition. This information system strategic planning plays a very important role in PT. XYZ thus creating alignment to achieve existing goals. The solution for information system needs is based on the strategic planning analysis that has been carried out, namely, producing nine information systems consisting of one information system that will be developed from existing applications and eight information systems for the proposed application. It also requires IT personnel to work on database servers and networks or to conduct training for each employee so that if there is damage to the system and infrastructure it can be directly handled. This was done due to the condition of the number of human resources and limited funds for strategic planning of information systems.

\section{REFERENCES}

Anharudin. (2015). Perencanaan Strategis Sistem Informasi untuk Meningkatkan Pelayanan Menggunakan Metode Ward and Peppard. Jurnal PROSISKO Vol. 2 No. 2, 2015.

Atmaja, W. H. (2002). Penyusunan Metodologi Perencanaan Strategis Sistem Informasi Berbasis Value Bisnis (Be Vissta Planning) untuk Meningkatkan Peran Strategis Sistem Informasi pada Suatu Organisasi (Bagian I). The Winners, 3(1), 3255.
Mulyani, Asri. (2017). Perencanaan Strategis Sistem Informasi Taman Satwa Menggunakan Metodologi Ward and Peppard. Sekolah Tinggi Teknologi Garut.

Rusdiana \& Irfan, Moch. (2014), Sistem Informasi Manajemen, Bandung: Pustaka Setia

Saputri, Nurul Adha Oktarini. (2015).Perencanaan Strategis Teknologi Informasi pada Universitas Tamansiswa Palembang dengan Metode Balanced Scorecard. Palembang.

Spriyanto, Bambang Eko.(2018). Perencanaan Strategis Sistem Informasi dan Teknologi Informasi untuk Sekolah Menengah Kejuruan Menggunakan Metodologi Wetherbe: Studi Kasus SMK Avicena Rajeg. Jurnal Ilmu Komputer, Vol. 3 No. 1, 2018.

Sriminangga, Nicka Puspita. (2013). Perencanaan Strategis Teknplogi Informasi pada Pondok Pesantren Annur II AL-Murtadlo Malang dengan Metode Wetherbe. Malang.

Supriyantoko, Iwan. (2018). Perancangan Strategis Sistem Informasi di SMK Diponegoro 1 Jakarta. Universitas Negeri Jakarta. ELINVO, 2018;3(2):1018

Ward, J., Peppard, J.(2002). Strategis Planning for Information System, West Sussex: John Wiley \& Sons Limited.

Wedhasmara, Ari. (2009). Langkah-langkah perancangan strategis sistem informasi dengan menggunakan metode ward and peppard. Jurnal Sistem Informasi (JSI), VOL. 1, NO. 1, 2009.

Yususf, Irwan, Utami. (2011). Rancangan Informasi Eksekutif untuk Bidang Akademik dan Kemahasiswaan di Universitas Sebelas Maret. Performa (2011)Vol. 10, No.2:131-140. 